\title{
Development and characterization of acid-doped polybenzimidazole/sulfonated polysulfone blend polymer electrolytes for fuel cells
}

\author{
Hasiotis, C.; Li, Qingfeng; Deimede, V.; Kallitsis, J. K.; Kontoyannis, C. G.; Bjerrum, Niels
}

Published in:

Journal of The Electrochemical Society

Link to article, DOI:

10.1149/1.1366621

Publication date:

2001

Document Version

Publisher's PDF, also known as Version of record

Link back to DTU Orbit

Citation (APA):

Hasiotis, C., Li, Q., Deimede, V., Kallitsis, J. K., Kontoyannis, C. G., \& Bjerrum, N. (2001). Development and characterization of acid-doped polybenzimidazole/sulfonated polysulfone blend polymer electrolytes for fuel cells. Journal of The Electrochemical Society, 148(5), A513-A519. https://doi.org/10.1149/1.1366621

\section{General rights}

Copyright and moral rights for the publications made accessible in the public portal are retained by the authors and/or other copyright owners and it is a condition of accessing publications that users recognise and abide by the legal requirements associated with these rights.

- Users may download and print one copy of any publication from the public portal for the purpose of private study or research.

- You may not further distribute the material or use it for any profit-making activity or commercial gain

- You may freely distribute the URL identifying the publication in the public portal 


\title{
Development and Characterization of Acid-Doped Polybenzimidazole/Sulfonated Polysulfone Blend Polymer Electrolytes for Fuel Cells
}

\author{
C. Hasiotis, ${ }^{a}$ Li Qingfeng, ${ }^{\text {b,* }}$ V. Deimede, ${ }^{\text {a,c }}$ J. K. Kallitsis, ${ }^{\text {a,c }}$ \\ C. G. Kontoyannis, ${ }^{\text {a,d,z }}$ and N. J. Bjerrum ${ }^{\mathrm{b}, *}$ \\ ${ }^{a}$ Institute of Chemical Engineering and High Temperature Chemical Processes, GR-265 00 Patras, Greece \\ ${ }^{b}$ Department of Chemistry, Technical University of Denmark, DK-2800 Lyngby, Denmark \\ ${ }^{c}$ Department of Chemistry and ${ }^{d}$ Department of Pharmacy, University of Patras, GR-265 00 Patras, Greece
}

\begin{abstract}
Polymeric membranes from blends of sulfonated polysulfones (SPSF) and polybenzimidazole (PBI) doped with phosphoric acid were developed as potential high-temperature polymer electrolytes for fuel cells and other electrochemical applications. The water uptake and acid doping of these polymeric membranes were investigated. Ionic conductivity of the membranes was measured in relation to temperature, acid doping level, sulfonation degree of SPSF, relative humidity, and blend composition. The conductivity of SPSF was of the order of $10^{-3} \mathrm{~S} \mathrm{~cm}^{-1}$. In the case of blends of PBI and SPSF it was found to be higher than $10^{-2} \mathrm{~S} \mathrm{~cm}^{-1}$. Much improvement in the mechanical strength is observed for the blend polymer membranes, especially at higher temperatures. Preliminary work has demonstrated the feasibility of these polymeric membranes for fuel-cell applications. (C) 2001 The Electrochemical Society. [DOI: 10.1149/1.1366621] All rights reserved.
\end{abstract}

Manuscript submitted October 19, 2000; revised manuscript received January 30, 2001.

Polymer electrolyte membrane fuel cells (PEMFCs) have attracted much attention during the last decades mainly due to their possible use in the future as power generators. ${ }^{1}$ The potential technological application of PEMFCs is limited by the poisoning effect of carbon monoxide. Traces of CO (5-10 ppm) cause a drastic decrease in the activity of anode catalysts. Recently, operation of these cells at higher temperatures, up to $200^{\circ} \mathrm{C}$, has been proposed as a possible way to enhance the tolerance of the catalysts to fuel impurities, e.g., $\mathrm{CO}^{2}$ However, the development of higher temperature PEMFCs requires an appropriate polymer electrolyte. The ideal polymer membrane electrolyte in such a fuel cell should exhibit thermal stability at elevated temperatures, easy preparation of thin and homogeneous membranes of large area, high ionic conductivity, low gas permeability, sufficient mechanical strength, and low cost.

Polybenzimidazole (PBI) membranes, being sulfonated, phosphonated, or doped with an acid, ${ }^{3,4}$ exhibit a proton conductivity at temperatures up to $200^{\circ} \mathrm{C}$. It is reported that this polymer membrane electrolyte has a high ionic conductivity, ${ }^{3-8}$ low methanol crossover rate, ${ }^{9}$ excellent thermal stability, ${ }^{10}$ nearly zero water drag coefficient, ${ }^{8,11}$ and enhanced activity for oxygen reduction. ${ }^{12,13}$ Fuel-cell tests with various types of fuel such as hydrogen, ${ }^{14}$ methanol, ${ }^{15}$ trimethoxymethane, ${ }^{16}$ and formic acid $^{17}$ have been reported. Besides, this polymer membrane electrolyte has also been used for other electrochemical applications. ${ }^{18}$

On the other hand, sulfonation of polyaromatic thermoplastics such as polysulfone has been an active subject in order to develop ion-exchange membranes for PEMFC ${ }^{19-21}$ and other applications. $^{22,23}$ It has been reported that sulfonation of polysulfone increases the glass transition temperature to higher than $200^{\circ} \mathrm{C} .{ }^{24,25}$ The cast membranes of sulfonated polysulfones (SPSF) exhibit good mechanical strength, flexibility, and low gas permeability. These properties are encouraging for further investigation of this polymer. Blends of PBI with SPSF have been prepared and studied with respect to their miscibility behavior. ${ }^{24}$ It was found that blends of PBI with SPSF show miscibility depending upon the composition of blends and the sulfonation degree of SPSF. In general, PBI-rich blends appear to be one compound system, as opposed to the SPSF rich blends where two phases were observed. The combination of SPSF with PBI might lead to a promising new polymer electrolyte. Besides, SPSF is a quite inexpensive polymeric material that results in lowering the cost of electrolyte. In the present work, an attempt

\footnotetext{
* Electrochemical Society Active Member

z E-mail: cgk@iceht.forth.gr
}

was made to study the electrochemical behavior of SPSF with various sulfonation degrees and its blends with PBI of different compositions.

\section{Experimental}

Polysulfone (molecular weight $c a$. 26,000, Aldrich) has been sulfonated to various degrees using chlorosulfonic acid as sulfonating agent, according to the procedure proposed by Johnson et al. ${ }^{26}$ The sulfonation degree (percentage of the introduced sulfonate group to polysulfone) of SPSF was determined by ${ }^{1} \mathrm{H}$ NMR and Fourier transform (FT)-Raman spectroscopy. Membranes of PBI (solution in dimethylacetamide containing 2 wt $\% \mathrm{LiCl}$, Celanese) with SPSF were prepared by solution casting from dimethylacetamide (DMAc, Aldrich). In the case of pure SPSF, dimethylformamide (DMF, Aldrich) was used as the solvent. The cast membranes were dried at $190^{\circ} \mathrm{C}$ under vacuum in order to remove residual solvent. The dryness of the membranes is important since plasticization effects due to remaining solvent may occur. ${ }^{24}$

The water uptake and acid doping of PBI-SPSF membranes were determined by immersing samples in distilled water and acid solution for a few days. The samples were weighed before and after the immersion and the weight gain was obtained. The doping level of phosphoric acid was varied by using $\mathrm{H}_{3} \mathrm{PO}_{4}$ of either different concentration at room temperature or of $85 \mathrm{wt} \%$ acid at various temperatures. The doping level of the membranes is defined as the molar percent of the acid $\left(\mathrm{mol} \% \mathrm{H}_{3} \mathrm{PO}_{4}\right)$ per repeat unit of the PBI polymer or per average repeat unit of PBI and SPSF, and was determined by comparing the weight changes before and after doping. In this way the obtained weight gain was due to both water and phosphoric acid. In order to separate the acid uptake and water uptake, the doped polymer membranes were dried at $110^{\circ} \mathrm{C}$ under vacuum for more than $10 \mathrm{~h}$ until an unchanged weight was reached. In this treatment the water content in the doped polymer membranes was removed and the acid-doping level was obtained.

Conductivity measurements were performed by means of a fourprobe cell as schematically illustrated in Fig. 1. The cell consisted of four platinum electrodes placed on one side of the polymeric membrane. Four stainless steel rods pressed the electrodes onto the membrane with the help of springs. In this longitudinal arrangement the electrodes were in good contact with the membrane while the sample was exposed to the atmosphere of the cell. The polymeric membranes were narrow $4 \times 1 \mathrm{~cm}$ strips. The thickness of the doped membranes was of the order of $100 \mu \mathrm{m}$ and measured using a micrometer before every experiment. Two platinum foils were used to apply current to the ends of the membrane while the other 


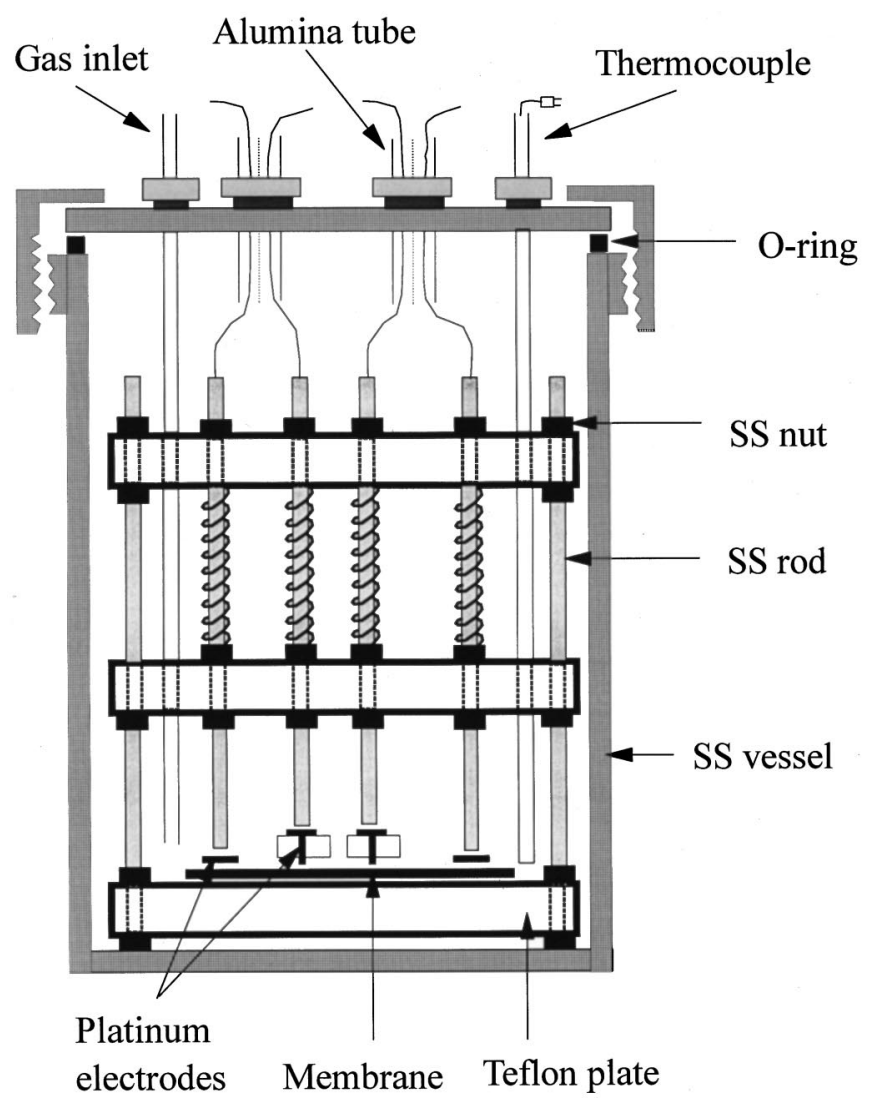

Figure 1. Setup used for conductivity measurements.

two platinum probe wires spaced $1 \mathrm{~cm}$ apart were employed to measure the potential drop along the film near the center of the sample. This cell was introduced in a stainless steel vessel that was immersed in an oil bath so as to control the temperature. The polymeric membrane was placed on a Teflon plate in order to be isolated from the stainless steel vessel. Also, ceramic tubes of alumina were used for the isolation of the extension of the electrodes. A thermocouple was arranged near the sample for monitoring its temperature. The relative humidity was controlled by passing a mixture of humidified and dry nitrogen through the cell and was monitored using a hygrometer. Two flow meters were used to control the ratio of dry and humidified nitrogen that were mixed in a chamber placed just before the cell. The measurements were carried out by a current interruption method using a potentiostat/galvanostat (EG\&G model 273) and an oscillator (Hitachi model V-650F).

Mechanical properties of the membranes were measured by means of tensile strength, i.e., the ultimate tensile stress when the sample breaks. The sample had an original cross section of about $1 \times 0.008 \mathrm{~cm}$ and was tested in a glass furnace, where the temperature was controlled. The tensile strength was measured as a function of doping level at different temperatures.

Platinum catalysts $(20 \% \mathrm{Pt})$ supported by carbon black (Vulcan XC-72R, Cabot) were prepared by chemical reduction of platinum chloroacid. The catalysts were applied onto a wet-proofed carbon paper (Toray TGP-H-120) by a tape-casting technique. Thus obtained gas diffusion electrodes were further impregnated with a $5 \%$ PBI solution in DMAc. The loading of the polymer in the catalyst layer was controlled in a range from 0.6 to $0.8 \mathrm{mg} \mathrm{cm}^{-2}$. Assemblies from the acid-doped polymer membranes and the impregnated electrodes were prepared by means of a hot-press at $150^{\circ} \mathrm{C}$ for 10 min. A single test cell $\left(5 \mathrm{~cm}^{2}\right)$ was made of graphite plates with gas channels. Two aluminum end plates with attached heaters were used to clamp the graphite plates. Fuel and oxidant gases were supplied by means of mass-flow controllers. Performance curves were ob- tained by a current step potentiometry. Potential values at various current densities were then taken from chronopotentiometric curves when a steady state was reached.

\section{Results and Discussion}

Water uptake and acid doping of PBI and blend membranes.-The water uptake of polymer membranes is of special importance, since water is involved in the electrode reactions and proton conduction through the membrane of PEMFCs. It is well known that PBI has a high affinity for moisture and is hydrophilic. This is possibly due to an intermolecular hydrogen bonding between $\mathrm{N}$ and $\mathrm{N}-\mathrm{H}$ groups in PBI and water. ${ }^{27}$ By immersing PBI membranes in distilled water for several days at room temperature, it is found in the present work that up to $20-21 \mathrm{w} / \mathrm{w} \%$ (with a dry polymer as basis) water can be absorbed by the pristine PBI membranes, corresponding to 3.4-3.6 water molecules per repeat unit of PBI.

Water absorption is also observed for SPSF membranes. The water uptake of the SPSF membranes might be attributed to the interactions between $\mathrm{H}_{2} \mathrm{O}$ and the sulfonate groups in SPSF. The sulfonation degree of the studied SPSF membranes was 36\%, corresponding to an ion exchange capacity (IEC) of 0.81 mequiv/g. It is found that, at room temperature, $8-10 \mathrm{w} / \mathrm{w} \%$ water is absorbed by the dry SPSF membranes, which have not experienced any pretreatment. This corresponds to about seven water molecules per sulfonate group. Brousse et al. ${ }^{25}$ claimed that the moisture gain by SPSF of IEC 0.635 and 0.9 mequiv/g (corresponding to sulfonation degrees around 30 and $40 \%$ ) at room temperature is 7 and $7.4 \mathrm{~mol}$ $\mathrm{H}_{2} \mathrm{O}$ per ionic site, respectively. Using SPSF of sulfonation degree $40.3 \%$ at room temperature, Lufrano et al. ${ }^{20}$ reported a water uptake of about $9 \mathrm{~mol} \mathrm{H}_{2} \mathrm{O} / \mathrm{SO}_{3} \mathrm{H}$ for the rehydrated membranes after drying at $30^{\circ} \mathrm{C}$ for $18 \mathrm{~h}$. This value became about $12 \mathrm{~mol} \mathrm{H} \mathrm{H}_{2} \mathrm{O} / \mathrm{SO}_{3} \mathrm{H}$ for the rehydrated membrane after drying at $70^{\circ} \mathrm{C}$ for $18 \mathrm{~h}$. As they suggested, these water uptake results confirmed the history dependence of the ionomer membranes, well known to perfluorosulfonic acid polymer membranes, e.g., Nafion. As suggested by Zawodzinski et al. ${ }^{28,29}$ and Hinatsu et al., ${ }^{30}$ the water uptake by the polymer membranes is essential for proton conductivity. As a comparison, Nafion membranes have a water uptake of about $22 \mathrm{~mol} \mathrm{H}_{2} \mathrm{O} / \mathrm{SO}_{3} \mathrm{H}$ from the liquid phase and about $16 \mathrm{~mol} \mathrm{H}_{2} \mathrm{O} / \mathrm{SO}_{3} \mathrm{H}$ from the vapor phase at room temperature, ${ }^{28-30}$ being much higher than the water uptake values for SPSF obtained in this work. It has been observed that the water uptake of the SPSF increases with the sulfonation degree or the ion-exchange capacity, ${ }^{20,21}$ the latter being found to increase linearly with the sulfonation degree. ${ }^{20}$ In the present work the water uptake is found to increase with increasing PBI content in the PBI-SPSF blends. At room temperature without any pretreatment, blends rich in PBI (75 w/w \%) absorb $18-19$ w/w \% water. In contrast, $10-12 \mathrm{w} / \mathrm{w} \%$ water can be absorbed by the dry blends rich in $\operatorname{SPSF}(75 \mathrm{w} / \mathrm{w} \%)$.

Since PBI possesses both donor and acceptor hydrogen-bonding sites, it is capable to participate in specific interactions. In the presence of acids or bases, a PBI polycation can be formed, resulting in acid or base neutralization and formation of a salt with the imidazole ring structure. An electrolyte active species dispersed within the polymer structure is a necessity for proton conduction. The proton conducting active species is phosphoric acid in the present study.

By immersing PBI membranes in a phosphoric acid solution, the weight gain of the polymer is due to both acid and water uptake. In the previous work, ${ }^{8}$ it was assumed that the water uptake by PBI membranes remained unchanged in the presence and absence of the acid. In the present work, efforts were made to determine the water contribution in the acid-doped PBI membranes. This was done by drying the doped polymer membranes at $110^{\circ} \mathrm{C}$ under vacuum while the weight of the doped polymer membranes was measured periodically. It appeared that an unchanged weight of the doped polymer membranes was reached after about $6 \mathrm{~h}$ under this condition. The weight loss is assumed to be due to the water uptake and the remaining weight is assumed to be the polymer purely doped with the acid. 


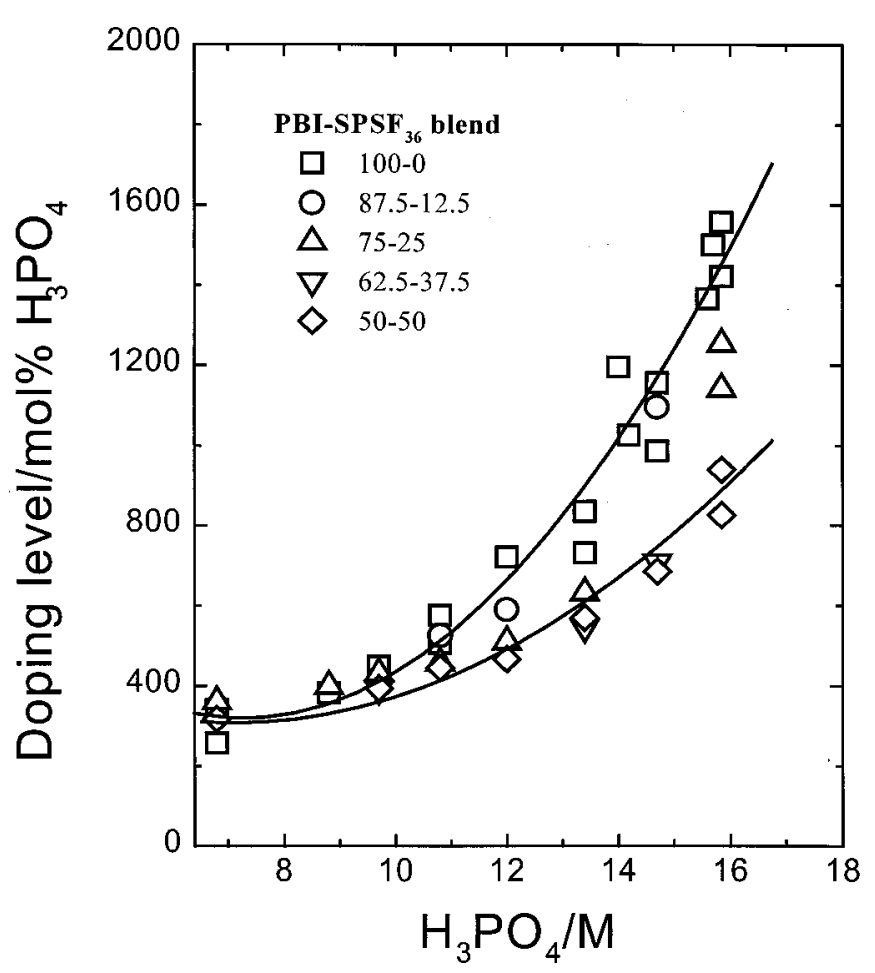

Figure 2. Doping levels of the blend membranes in molar percent of $\mathrm{H}_{3} \mathrm{PO}_{4}$ per repeat unit of the polymer as a function of concentration of the doping acid at room temperature. The composition of the blend polymers is indicated in the figure. The sulfonation degree of the SPSF is $36 \%$.

The water-uptake by PBI membranes from a phosphoric acid solution is found to be around $3.5 \mathrm{~mol} \mathrm{H}_{2} \mathrm{O}$ per repeat unit of PBI as the concentration of the acid increases from zero (pure water) to 6.0 M. Further increase in the acid concentration results in an increase in the water uptake. For 7.0 and $9.7 \mathrm{M} \mathrm{H}_{3} \mathrm{PO}_{4}$, for example, the water uptake by PBI membranes is found to be 4.0 and 5.6 mol $\mathrm{H}_{2} \mathrm{O}$, respectively.

The acid-doping level of the PBI membranes was obtained accordingly, as shown in Fig. 2 as a function of the acid concentration at room temperatures. For pure PBI membranes $(\square)$, as can be seen from the figure, a doping level of around $500 \mathrm{~mol} \% \mathrm{H}_{3} \mathrm{PO}_{4}$ can be achieved by using 9-11 $\mathrm{M} \mathrm{H}_{3} \mathrm{PO}_{4}$ solution at room temperature, which is in good agreement with other reports. $3,6,9,12$

For SPSF membranes of a sulfonation degree lower than $50 \%$, as studied in the present work, the acid doping level was found to be lower than $50 \mathrm{~mol} \% \mathrm{H}_{3} \mathrm{PO}_{4}$. Direct doping of SPSF with phosphoric acid was also attempted by addition of the desired amount of $\mathrm{H}_{3} \mathrm{PO}_{4}$ in a solution of SPSF in DMF before the membranes were cast. It is noteworthy that direct doping allows us to prepare selfstanding doped SPSF membranes with high sulfonation degree (higher than 50\%). These polymers have a brittle nature and therefore they do not form freestanding films either from solution or from melt pressing. By increasing the doping level to more than 300 mol $\% \mathrm{H}_{3} \mathrm{PO}_{4}$, nonhomogeneous membranes exhibiting patches of different physical characteristics (e.g., thickness, coloration, etc.), were obtained using the direct-doping procedure.

PBI-SPSF blend membranes can be readily doped with $\mathrm{H}_{3} \mathrm{PO}_{4}$ after immersion in the acid solution. It was found that the doping level increases upon increasing the acid concentration, temperature, and the PBI/SPSF ratio. In the studied blend composition (from 0 to $50 \%$ SPSF), the doping levels of blend membranes from a certain concentration of the acid are lower than that for pure PBI, as seen from Fig. 2.

Ionic conductivity of SPSF.- Ionic conductivity of the mem-

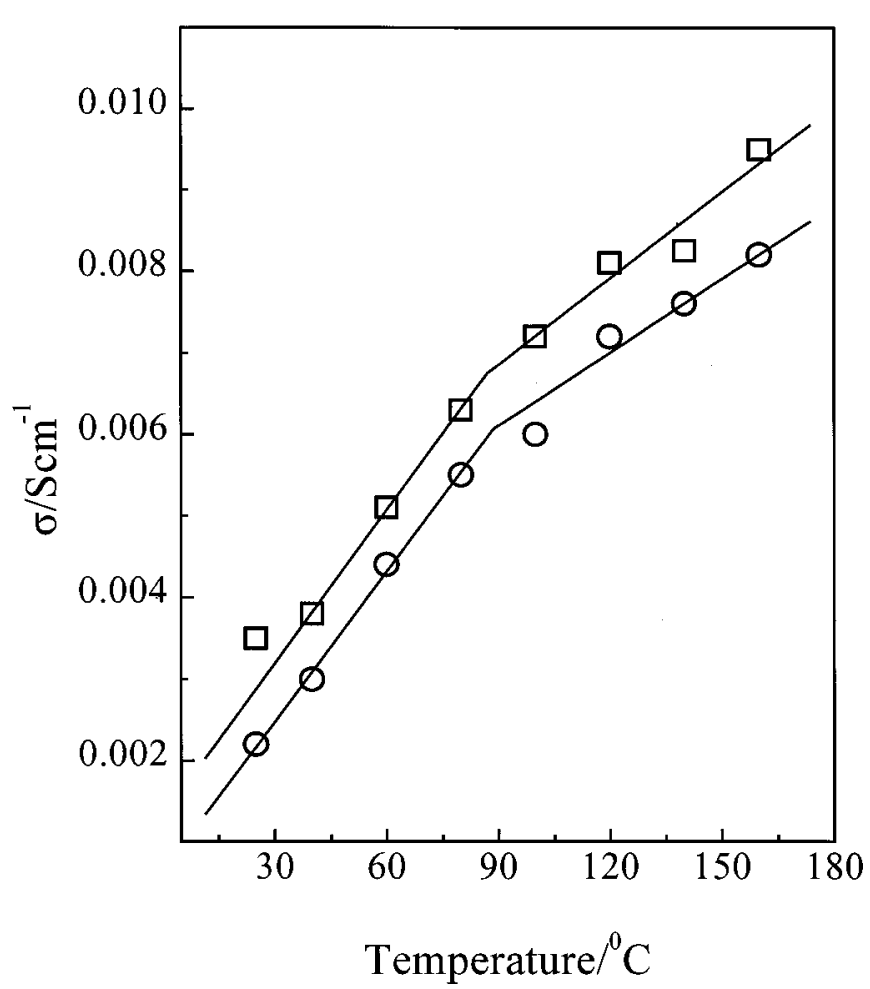

Figure 3. Temperature dependence of ionic conductivity of acid-doped SPSF: ( $\square$ ) sulfonation degree $44 \%$ and doping level $30 \mathrm{~mol} \% \mathrm{H}_{3} \mathrm{PO}_{4}$ and (O) sulfonation degree $10 \%$ and doping level $45 \mathrm{~mol} \% \mathrm{H}_{3} \mathrm{PO}_{4}$. The relative humidity is $80 \%$.

branes under investigation was measured as a function of relative humidity, acid-doping level, sulfonation degree of SPSF, and temperature. When the relative humidity increases in the range between 30 and $80 \%$ the conductivity was found to increase slightly $(\sim 2-$ $4 \%$ ). Poinsignon et al. ${ }^{21}$ also reported a slight increase in the proton conductivity with relative humidity from 70 to $110 \%$ at $50^{\circ} \mathrm{C}$ for SPSF of IEC 1.8 mequiv/g (corresponding to a sulfonation degree around $80 \%$ ), though a dramatic increase in the proton conductivity is observed for SPSF filled with phosphatoantimonic acid at a relative humidity near $100 \%$.

The ionic conductivity of acid-doped SPSF membranes increases upon increasing temperature (Fig. 3). In a range from room temperature to $160^{\circ} \mathrm{C}$, conductivity of the order $10^{-3} \mathrm{~S} \mathrm{~cm}^{-1}$ was obtained. The relatively low ionic conductivity should be attributed to the low sulfonation degree and the low phosphoric acid doping level. In the studied range of the sulfonation degree (from 10 to 44\%), a small dependence of conductivity on sulfonation degree of SPSF was observed, though a high conductivity was reported at much higher sulfonation degrees. ${ }^{20,21}$ Actually, the conductivity of SPSF was found to increase exponentially with the increase of sulfonation degree. ${ }^{20}$ In the previous works, ${ }^{20,21}$ the conductivity was studied in relation to the water uptake of SPSF membranes. In the present work, the SPSF membrane was doped with phosphoric acid and the doping level seems more dominant for affecting the conductivity. A small decrease in the doping level reduces the conductivity even when the sulfonation degree is higher (Fig. 3). However, higher acid-doping levels cannot be achieved. As stated above a doping level of SPSF membranes of $300 \mathrm{~mol} \% \mathrm{H}_{3} \mathrm{PO}_{4}$ was achieved when they were directly cast from a solution in which phosphoric acid had been added. These membranes, however, exhibited no conductivity.

As shown in Fig. 3, there are two regions where the conductivity increases linearly with temperature. The slopes of the Arrhenius plots of conductivity between 298-363 and 363-433 K (not shown) give the activation energy of $12.8-14.8$ and $6.1-6.7 \mathrm{~kJ} / \mathrm{mol}$, respec- 


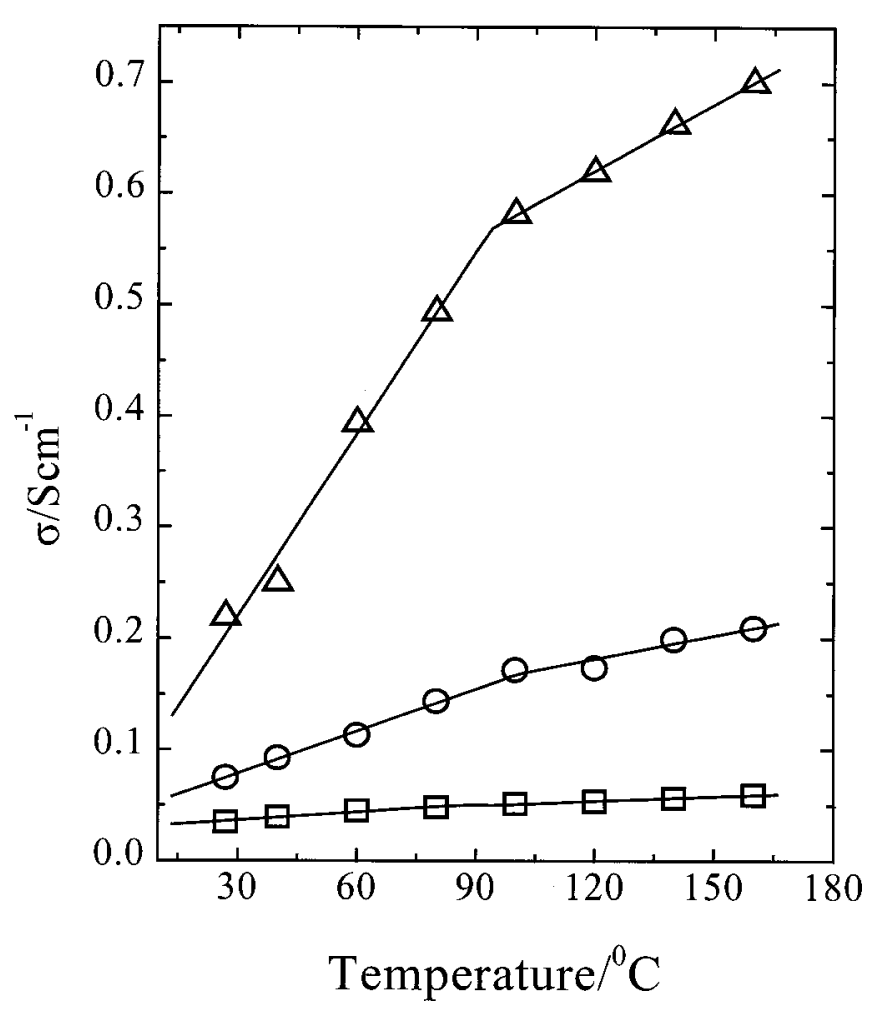

Figure 4. Dependence of ionic conductivity of PBI-SPSF blends on aciddoping level. The content of PBI in the blends is $75 \mathrm{wt} \%$. The sulfonation degree of the SPSF is 36\%. Doping level $\left(\mathrm{mol} \% \mathrm{H}_{3} \mathrm{PO}_{4}\right)$ : ( $\square$ ) 500, $(\bigcirc)$ 1100 , and $(\triangle) 2300$. Relative humidity $80 \%$.

tively. The change of the activation energy might be connected with the presence of water in the membranes. As reported, ${ }^{20}$ water is involved in the conduction mechanism. The presence of water in SPSF membranes results in a phase separation between the SPSF backbone and the sulfonate-water clusters that are formed. These ionic clusters permit the ion migration through the membranes. In the present work the SPSF membranes were doped with $\mathrm{H}_{3} \mathrm{PO}_{4}$ $(85 \%)$. It means that not only phosphoric acid but also water is present in the membranes. Consequently, both phosphoric acid and sulfonate-water clusters are the conducting active species. As stated previously, the conductivity increases slightly when the relative humidity increases in the range between 30 and $80 \%$. This behavior implies that in this range, the atmospheric humidity does not seem to influence significantly the retention of water in the membrane. The change of the activation energy, which occurs at $\sim 90^{\circ} \mathrm{C}$, might be attributed to the phase transition of water at elevated temperatures.

Ionic conductivity of PBI-SPSF blends.-Dependence of ionic conductivity on doping level and relative humidity.-The conductivity of blends was found to be higher than $10^{-2} \mathrm{~S} \mathrm{~cm}^{-1}$ and increase with temperature. These polymeric materials are conductive after doping with an acid. The acid-doping level is therefore expected to influence the ionic conductivity of blends. For blend membranes rich in PBI (Fig. 4) doped with $500 \mathrm{~mol} \% \mathrm{H}_{3} \mathrm{PO}_{4}$, the conductivity was found to be in the range $2 \times 10^{-2}$ and $10^{-1} \mathrm{~S} \mathrm{~cm}^{-1}$. The conductivity increases up to $2 \times 10^{-1} \mathrm{~S} \mathrm{~cm}^{-1}$ at $160^{\circ} \mathrm{C}$ for a doping level of $1000 \mathrm{~mol} \% \mathrm{H}_{3} \mathrm{PO}_{4}$. Further increase of the doping level results in significant increases of conductivity. Using hot phosphoric acid $\left(130^{\circ} \mathrm{C}\right)$, a doping level as high as $2300 \mathrm{~mol} \%$ can be achieved, which seems to be the limit since at higher doping level degradation of the membranes occurs. Under these extreme conditions the conductivity is measured up to $7 \times 10^{-1} \mathrm{~S} \mathrm{~cm}^{-1}$ at $160^{\circ} \mathrm{C}$. However,

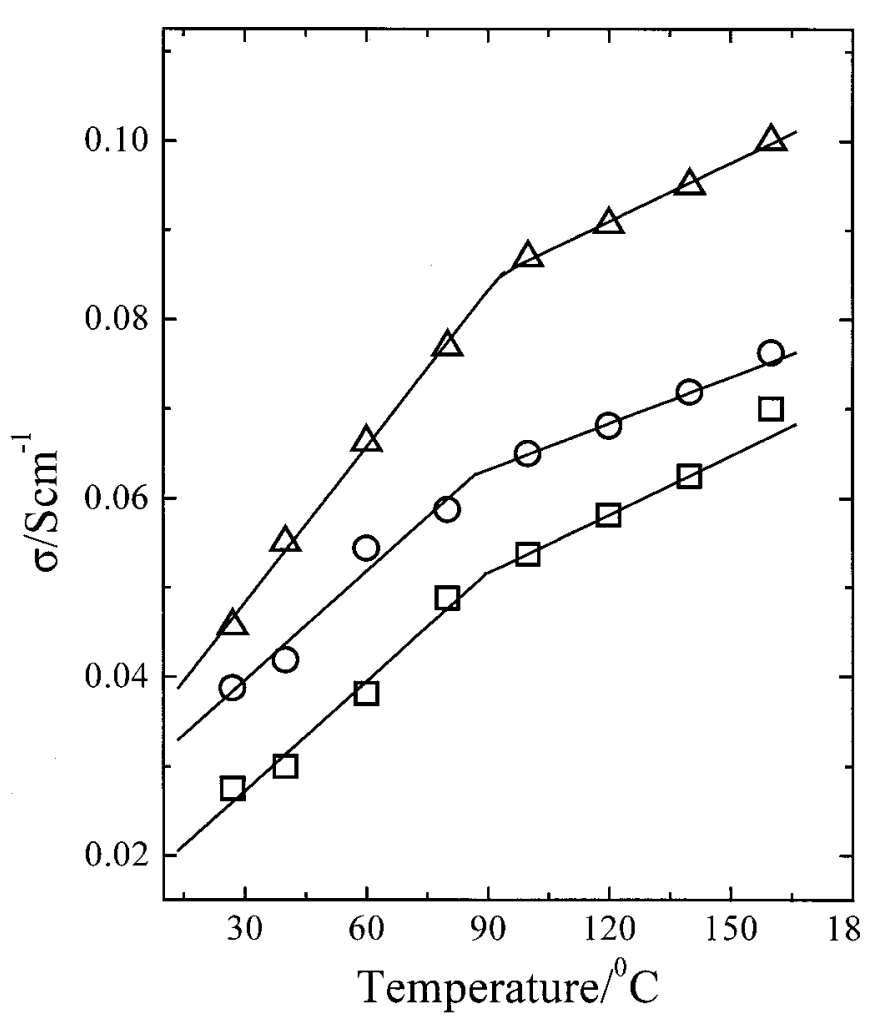

Figure 5. Dependence of ionic conductivity of PBI-SPSF blends on sulfonation degree of SPSF. The doping level is $500 \mathrm{~mol}_{\%} \mathrm{H}_{3} \mathrm{PO}_{4}$. The content of PBI in the blends is $75 \mathrm{wt} \%$. The sulfonation degree of the SPSF is: ( $\square$ ) 20, (O) 36 , and $(\triangle) 70 \%$. Relative humidity $80 \%$.

high doping levels $\left(>1000 \mathrm{~mol} \% \mathrm{H}_{3} \mathrm{PO}_{4}\right)$ are not desirable for fuelcell applications, since membranes of very low mechanical strength are produced.

Relative humidity does not seem to influence significantly the conductivity of blends since a $\sim 3-5 \%$ increase in ionic conductivity was recorded when the relative humidity was gradually increased from 30 to $80 \%$. This is in accordance with previous results since PBI can be used with low humidification ${ }^{6}$ while conductivity of SPSF, as stated above, is slightly dependent on relative humidity. As a result, the blends of PBI with SPSF could also be expected to be operational with low humidification.

Dependence of ionic conductivity on sulfonation degree and PBI/ SPSF ratio.- In the case of pure SPSF, the dependence of conductivity on sulfonation degree was not studied in the present work. The blends rich in PBI are readily impregnated with $\mathrm{H}_{3} \mathrm{PO}_{4}$ and the conductivity is found to increase upon increasing sulfonation degree of SPSF. This behavior is illustrated in Fig. 5 and implies that not only the acid-doped PBI but also sulfonate sites of SPSF are involved in the conduction mechanism. The sulfonation degree of SPSF should not be lower than $20 \%$, since SPSF with very low sulfonation degree is not miscible with PBI. ${ }^{24}$ When the sulfonation degree is equal to $20 \%$, the conductivity is found to be $7 \times 10^{-2}$ $\mathrm{S} \mathrm{cm}^{-1}$ at elevated temperatures for blends rich in PBI (Fig. 5). For blends with the same composition and doping level but higher sulfonation degree $(70 \%)$, the conductivity is found to be $10^{-1} \mathrm{~S} \mathrm{~cm}^{-1}$ at $160^{\circ} \mathrm{C}$. Since for blends rich in PBI, even with low sulfonation degree of SPSF, the conductivity is found to be in the range of $10^{-2}$ to $10^{-1} \mathrm{~S} \mathrm{~cm}^{-1}$, these blends are preferable because of their improved mechanical behavior compared to those with high sulfonation degree.

The ionic conductivity was also measured as a function of composition of the blends. As depicted in Fig. 6 for PBI-SPSF membranes with sulfonation degree of $36 \%$, even for blends with low 


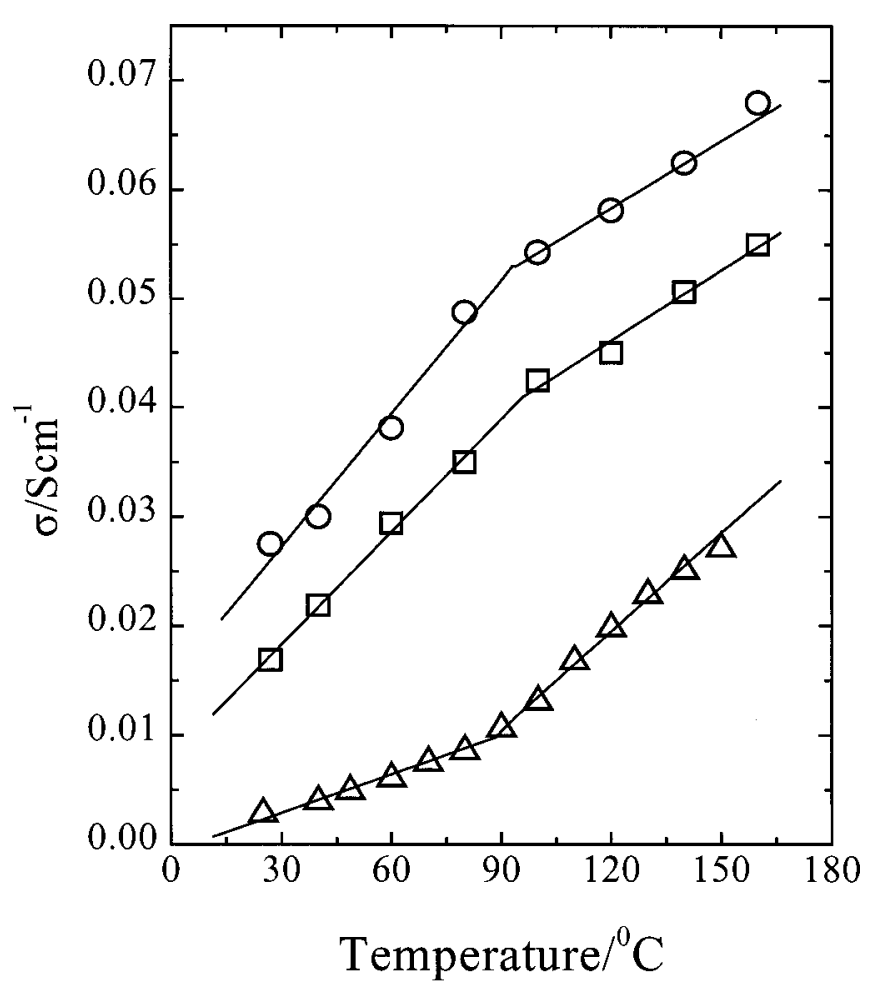

Figure 6. Dependence of ionic conductivity of PBI-SPSF blends on composition, relative humidity $80 \%$ : (O) PBI content 75 wt \%, doping level 500 mol $\% \mathrm{H}_{3} \mathrm{PO}_{4}$, and the sulfonation degree of SPSF is $20 \%$; ( $\square$ ) PBI content 20 wt $\%$, doping level $430 \mathrm{~mol} \% \mathrm{H}_{3} \mathrm{PO}_{4}$, and the sulfonation degree of SPSF is $20 \%$; and $(\triangle)$ pure PBI doped with $500 \mathrm{~mol} \% \mathrm{H}_{3} \mathrm{PO}_{4}$.

content of PBI that exhibit two phases, ${ }^{24}$ the conductivity is still of the order of $10^{-2} \mathrm{~S} \mathrm{~cm}^{-1}$, higher than that of pure PBI under the same doping conditions. The conductivity of PBI at a doping level of $500 \mathrm{~mol} \% \mathrm{H}_{3} \mathrm{PO}_{4}$ is found to be $2.7 \times 10^{-2} \mathrm{~S} \mathrm{~cm}^{-1}$ at $150^{\circ} \mathrm{C}$ in a humidified atmosphere. The conductivity values reported in the literature are scattered. Due to the various experimental conditions, comparison cannot be straightforward. Wainright et al. ${ }^{3}$ reported a conductivity value of $5 \times 10^{-3} \mathrm{~S} \mathrm{~cm}^{-1}$ at $150^{\circ} \mathrm{C}$ in a dry atmosphere for a PBI membrane doped with $501 \mathrm{~mol} \% \mathrm{H}_{3} \mathrm{PO}_{4}$. They also found that the conductivity of PBI, at the same temperature and doping level, increases with water vapor activity up to $3 \times 10^{-2}$ $\mathrm{S} \mathrm{cm}{ }^{-1}$ at $0.2 p_{\mathrm{H}_{2} \mathrm{O}} / p_{\text {sat }}$. Fontanella et al. ${ }^{6}$ obtained a conductivity of $4.5 \times 10^{-5} \mathrm{~S} \mathrm{~cm}^{-1}$ for dry PBI doped with $600 \mathrm{~mol} \% \mathrm{H}_{3} \mathrm{PO}_{4}$ at room temperature. Using anhydrous mixtures of $\mathrm{PBI}$ and $\mathrm{H}_{3} \mathrm{PO}_{4}$, Bouchet et al. ${ }^{5}$ reported an anhydrous conductivity of $7 \times 10^{-6}$ $\mathrm{S} \mathrm{cm}{ }^{-1}$ at a temperature of $30^{\circ} \mathrm{C}$ and doping level of 305 mol \% $\mathrm{H}_{3} \mathrm{PO}_{4}$.

Dependence of ionic conductivity on dehumidification.-As discussed previously, the PBI-SPSF blend membranes exhibit higher conductivity than the pure $\mathrm{PBI}$ membrane. This might be attributed to the interaction not only between $\mathrm{H}_{3} \mathrm{PO}_{4}$ and the $\mathrm{N}-\mathrm{H}$ groups of PBI, but also between $\mathrm{H}_{3} \mathrm{PO}_{4} / \mathrm{H}_{2} \mathrm{O}$ and the sulfonate groups of SPSF. The question which arises from this speculation is whether the high conductivity of blends can be kept constant for a long time, since a long-term performance is essential for any application of the membranes to a PEMFC. At high temperatures $\left(>150^{\circ} \mathrm{C}\right)$ difficulty of the management of water inside the membrane for a long period of time might appear, and as a result the ionic conductivity of the polymer electrolytes might decrease. Besides, the operation of a PEMFC without any humidification of gases is desired because it simplifies the construction of the cell system.

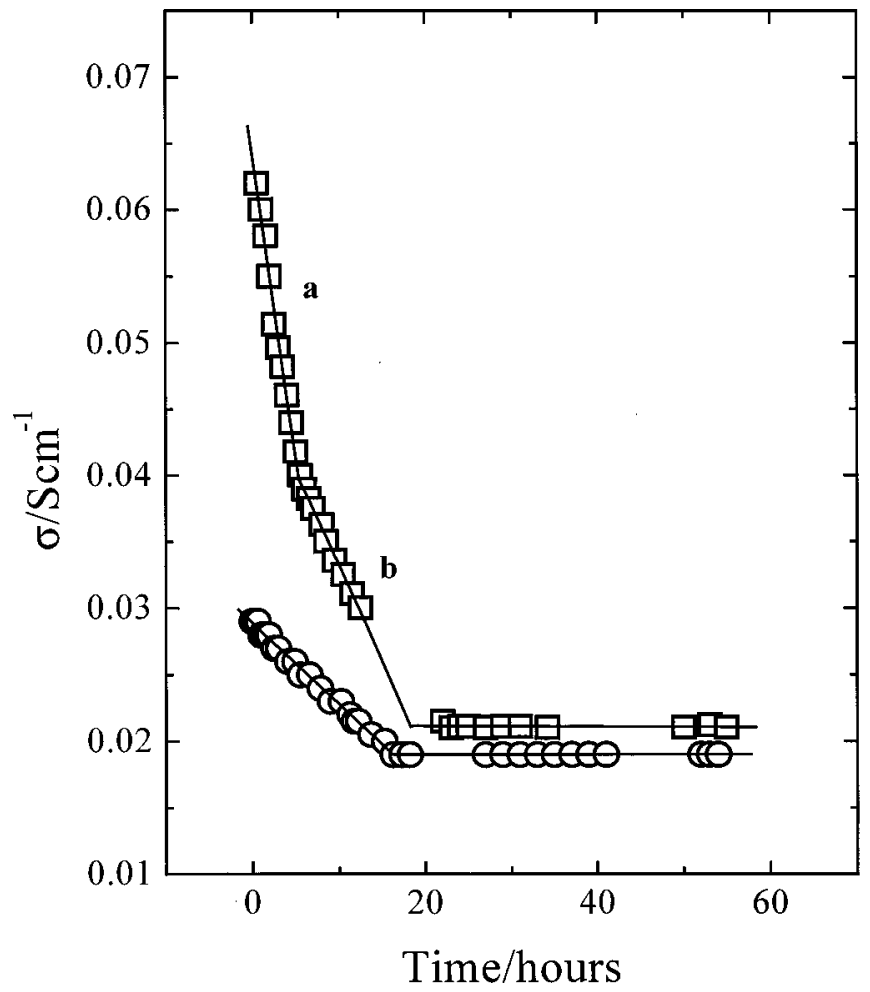

Figure 7. Dependence of ionic conductivity of $(\bigcirc)$ PBI and ( $\square$ ) PBI-SPSF blends on time without humidification at $175^{\circ} \mathrm{C}$. The doping level is $500 \mathrm{~mol}$ $\% \mathrm{H}_{3} \mathrm{PO}_{4}$. The content of $\mathrm{PBI}$ in the blends is $75 \mathrm{wt} \%$. Sulfonation degree of the SPSF is $30 \%$.

An experiment was carried out using PBI-SPSF 30 (75/25) and PBI membranes in an environment without any humidification at $175^{\circ} \mathrm{C}$ in order to evaluate the time dependence of ionic conductivity at elevated temperature. The decrease of ionic conductivity for both the blend and the pure PBI is shown in Fig. 7. The conductivity was stabilized after approximately $20 \mathrm{~h}$ to $2.1 \times 10^{-2} \mathrm{~S} \mathrm{~cm}^{-1}$, while in the case of PBI the conductivity also reached a plateau after $20 \mathrm{~h}$ at $1.9 \times 10^{-2} \mathrm{~S} \mathrm{~cm}^{-1}$. The only difference between PBI and the blend, besides the lower conductivity exhibited initially by PBI, is that for the PBI-SPSF blend the linear dependence of conductivity $v s$. time exhibits two regions with different slopes marked $\mathrm{a}$ and $\mathrm{b}$ in Fig. 7. A remarkable decrease of conductivity is observed, in the case of the blend, during the first $4 \mathrm{~h}$ (slope a). This behavior confirms that the higher conductivity of blends measured in a humidified atmosphere should be attributed to the retention of water in membranes. Sulfonate groups might interact with water and in this way the conductivity of blends is significantly influenced. When the membranes are dehumidified, the conductivities of both PBI and the blend were found to have similar values.

Mechanical strength measurements.-For the acid-doped PBI membranes, high doping levels give high conductivity. As reported previously, ${ }^{8}$ however, the tensile strength of acid-doped PBI membranes is reduced significantly as the acid-doping level increases, especially at higher temperatures.

On the other hand, polysulfone exhibits excellent mechanical properties. The elongation at break for polysulfone, for example, is reported to be $50-100 \%$, compared to $1.8-3.0 \%$ for PBI. ${ }^{31}$ For the sulfonated polysulfone at IEC of $0.98 \mathrm{mequiv} / \mathrm{g}$ (sulfonation degree about $43 \%$ ), Brousse et al. reported a tensile stress of 1100 and 330 $\mathrm{kgf} \mathrm{cm}-2$ for the dry and wet polymer, respectively.

For the PBI-SPSF blend polymer membranes, the mechanical strength is shown in Fig. 8 and 9 as a function of the membrane doping level at 25 and $150^{\circ} \mathrm{C}$, respectively. No improvement was 


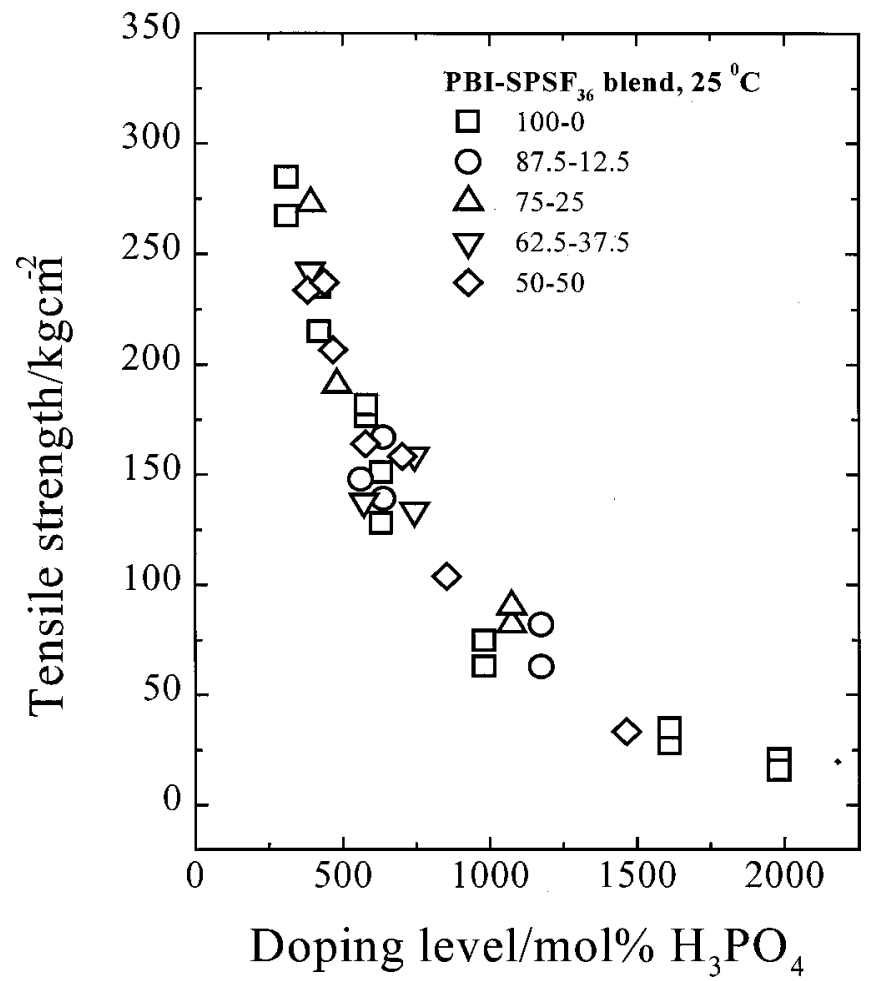

Figure 8. Tensile strength of the blend membranes as a function of doping level at room temperature. Composition of the blend polymers is indicated in the figure. Sulfonation degree of the SPSF is $36 \%$.

observed for blend polymer membrane electrolytes at room temperature. At $150^{\circ} \mathrm{C}$, however, the mechanical properties of membranes

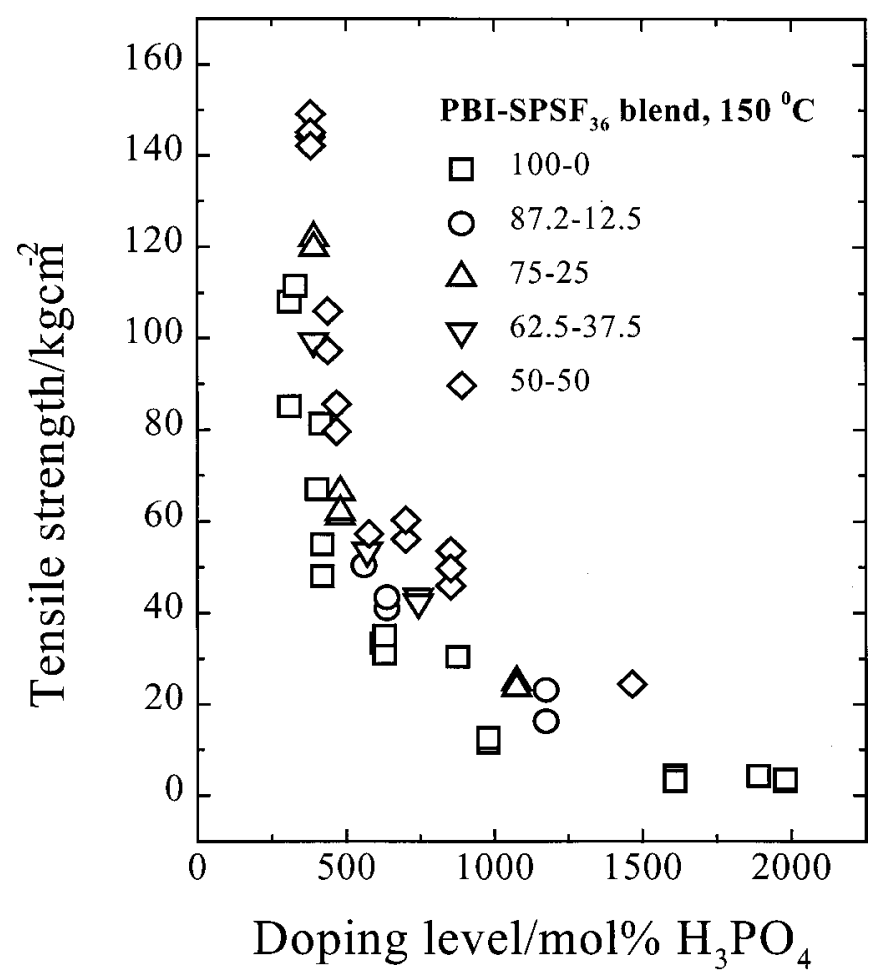

Figure 9. Tensile strength of the blend membranes as a function of doping level at $150^{\circ} \mathrm{C}$. Composition of the blend polymers is indicated in the figure. The sulfonation degree of the SPSF is $36 \%$.

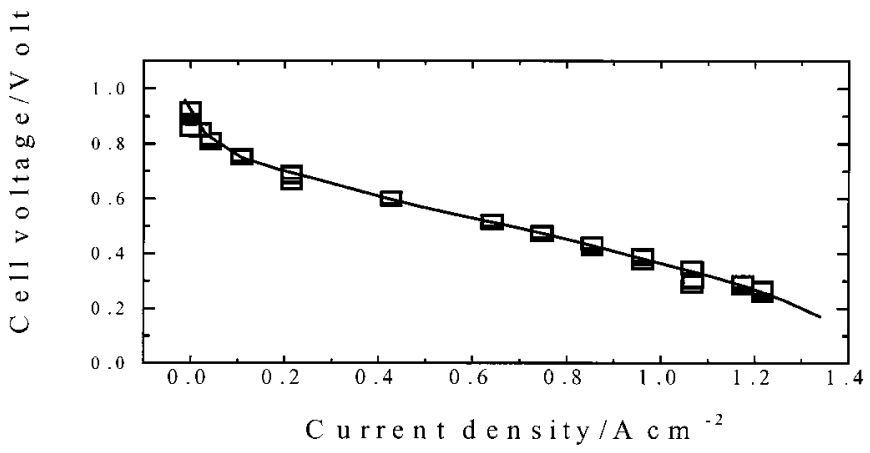

Figure 10. Cell voltage vs. current density curves for a PEM fuel cell based on the blend membrane electrolyte. Temperature $190^{\circ} \mathrm{C}$. Electrodes: platinum loading of $0.48 \mathrm{mg} / \mathrm{cm}^{2}$ for both anode and cathode. Membrane: $75 \%$ PBI-25\% SPSF (sulfonation degree 36\%), doped with 455 mol \% $\mathrm{H}_{3} \mathrm{PO}_{4}$. Both oxygen and hydrogen are at an absolute pressure of 1 bar and a flow rate of $40 \mathrm{~mL} \mathrm{~min}^{-1} \mathrm{~cm}^{-2}$.

were much improved for blend polymer electrolytes (see Fig. 9). At a doping level of about 450-660 mol $\% \mathrm{H}_{3} \mathrm{PO}_{4}$, for example, the tensile stress for pure PBI membranes is in a range of $25-62 \mathrm{kgf}$ $\mathrm{cm}^{-2}$, while for $50-50 \mathrm{~mol} \%$ PBI-SPSF blends it is as high as $58-115 \mathrm{kgf} \mathrm{cm}^{-2}$.

Fuel-cell tests.-The potential application of these membranes to fuel cells has been demonstrated and the preliminary results are shown in Fig. 10. The noble metal catalyst loading was $0.45 \mathrm{mg}$ $\mathrm{cm}^{-2}$ for both electrodes. The membrane electrolyte was $75 \%$ PBI$25 \%$ SPSF (sulfonation degree 36\%) blend doped at an acid doping level of $455 \mathrm{~mol} \% \mathrm{H}_{3} \mathrm{PO}_{4}$. It should be noted that the fuel cell operated with no humidification for either hydrogen or oxygen. Both gases were under atmospheric pressure. At a cell voltage of $0.5 \mathrm{~V}$, a current density of $650 \mathrm{~mA} / \mathrm{cm}^{2}$ was obtained, corresponding to a power density of over $0.3 \mathrm{~W} / \mathrm{cm}^{2}$. This performance is achieved with unoptimized electrodes and is comparable to that of pure PBI. ${ }^{8,14}$ Further development of the fuel-cell technology by optimizing electrodes and membrane electrolytes is in progress.

\section{Conclusions}

Blend polymer membranes of sulfonated polysulfones and polybenzimidazole were developed and characterized as potentially high temperature polymer electrolytes for fuel cells. The water uptake and acid doping of the blend polymeric membranes were investigated. The ionic conductivity of acid-doped sulfonated polysulfones and their blends with polybenzimidazole was measured. Conductivity of $10^{-3} \mathrm{~S} \mathrm{~cm}^{-1}$ level was obtained for the SPSF membranes at a very low acid-doping level. The acid-doped PBI-SPSF blend membranes exhibit ionic conductivity over $10^{-2} \mathrm{~S} \mathrm{~cm}^{-1}$, which is higher than pure PBI membranes under the same doping conditions. The electrical conductivity was found to increase slightly with atmospheric humidity. The blend polymer membranes exhibit much improved mechanical strength compared with pure PBI membranes, especially at higher temperatures. Fuel-cell tests have demonstrated the feasibility of the blend polymer electrolyte for polymer membrane fuel-cell operation at temperatures up to $200^{\circ} \mathrm{C}$, although data on prolonged operation are needed to verify the performance of these blends.

\section{Acknowledgments}

Financial assistance from the European Commission in the framework of the Non Nuclear Energy Program JOULE III (contract no. JOE3 CT97 0045) is acknowledged.

The Institute of Chemical Engineering and High-Temperature Chemical Processes assisted in meeting the publication costs of this article. 


\section{References}

1. H. P. Dhar, J. Electroanal. Chem., 357, 237 (1993).

2. R. F. Savinell, E. Yeager, D. Trysk, U. Landau, J. Wainright, D. Weng, K. Lux, M Litt, and C. Rogers, J. Electrochem. Soc., 141, L46 (1994).

3. J. S. Wainright, J. T. Wang, D. Weng, R. F. Savinell, and M. Litt, J. Electrochem. Soc., 142, L121 (1995).

4. X. Glipa, M. E. Haddad, D. J. Jones, and J. Roziere, Solid State Ionics, 97, 323 (1997).

5. R. Bouchet and E. Siebert, Solid State Ionics, 118, 287 (1999)

6. J. J. Fontanella, M. C. Wintersgill, J. S. Wainright, R. F. Savinell, and M. Litt, Electrochim. Acta, 43, 1289 (1998).

7. M. Kawahara, J. Morita, M. Rikukawa, K. Sanui, and N. Ogata, Electrochim. Acta, 45, 1395 (2000).

8. Li Qingfeng, H. A. Hjuler, and N. J. Bjerrum, J. Appl. Electrochem., Accepted for publication (2001).

9. J-T. Wang, S. Wasmus, and R. F. Savinell, J. Electrochem. Soc., 143, 1233 (1996).

10. S. R. Samms, S. Wasmus, and R. F. Savinell, J. Electrochem. Soc., 143, 1225 (1996).

11. D. Weng, J. S. Wainright, U. Landau, and R. F. Savinell, J. Electrochem. Soc., 143, 1260 (1996).

12. S. K. Zecevic, J. S. Wainright, M. H. Litt, S. Lj. Gojkovic, and R. F. Savinell, J. Electrochem. Soc., 144, 2973 (1997).

13. L. Qingfeng, H. A. Hjuler, and N. J. Bjerrum, Electrochim. Acta, 45, 4219 (2000).

14. J-T. Wang, R. F. Savinell, J. Wainright, M. Litt, and H. Yu, Electrochim. Acta, 41, 193 (1996).

15. J-T. Wang, J. S. Wainright, R. F. Savinell, and M. Litt, J. Appl. Electrochem., 26, 751 (1996).

16. J-T. Wang, W. F. Lin, M. Weber, S. Wasmus, and R. F. Savinell, Electrochim. Acta, 43, 3821 (1998).
17. M. Weber, J-T. Wang, S. Wasmus, and R. F. Savinell, J. Electrochem. Soc., 143, L158 (1996).

18. R. Bouchet, E. Siebert, and G. Vitter, J. Electrochem. Soc., 144, L95 (1997).

19. B. Baradie, C. Poinsignon, J. Y. Sanchez, Y. Piffard, G. Vitter, N. Bestaoui, D. Foscallo, A. Denoyelle, D. Delabouglise, and M. Vaujany, J. Power Sources, 74, 8-16 (1998).

20. F. Lufrano, G. Squadrito, A. Patti, and E. Passalacqua, J. Appl. Polym. Sci., 77, 1250 (2000)

21. C. Poinsignon, I. Amodio, D. Foscallo, and J. Y. Sanchez, Mater. Res. Soc. Symp. Proc., 548, 307 (1999).

22. J. Kerres, W. Cui, and S. Reichle, J. Polym. Sci., Part A: Polym. Chem., 34, 2421 (1996).

23. Y. Matsumoto, M. Sudoh, and Y. Suzuki, J. Membr. Sci., 158, 55 (1999).

24. V. Deimede, G. A. Voyiatzis, J. K. Kallitsis, L. Qingfeng, and N. J. Bjerrum, Macromolecules, 33, 7609 (2000).

25. Cl. Brousse, R. Chapurlat, and J. P. Quentin, Desalination, 18, 137 (1976).

26. B. C. Johnson, I. Yilgor, C. Tranc, M. Iqbal, J. P. Wightman, D. R. Lloyd, and J. E. MacGrath, J. Polym. Sci., Polym. Chem. Ed., 22, 721 (1984).

27. T-S. Chung, Rev. Macromol. Chem. Phys., C37, 277 (1997).

28. T. A. Zawodzinski, Jr., T. E. Springer, J. Davey, R. Jestel, C. Lopez, J. Valerio, and S. Gottesfeld, J. Electrochem. Soc., 140, 1981 (1993).

29. T. A. Zawodzinski, Jr., C. Derouin, S. Radzinski, R. J. Sherman, V. T. Smith, T. E. Springer, and S. Gottesfeld, J. Electrochem. Soc., 140, 1041 (1993).

30. J. T. Hinatsu, M. Mizuhata, and H. Takenaka, J. Electrochem. Soc., 141, 1493 (1994).

31. Specialty Polymers, R. W. Dyson, Editor, Blackie Academic \& Professional, London (1998). 